\title{
Canadian Crudes: A Comparative Study of SARA Fractions from a Modified HPLC Separation Technique
}

\author{
J. Woods*, J. Kung, D. Kingston, L. Kotlyar, B. Sparks and T. McCracken \\ National Research Council of Canada, Institute for Chemical Process and Environmental \\ Technology, 1200 Montreal Rd., Ottawa, Ontario - Canada, KIA OR6 \\ e-mail: john.r.woods@nrc.ca - judy.kung@nrc.ca - david.kingston2@nrc-cnrc.gc.ca - lubakotlyar@nrc.ca - \\ Vbedeta@aol.com - thom.mccracken@nrc.ca \\ * Corresponding author
}

\begin{abstract}
Résumé - Pétroles bruts canadiens : étude comparative des fractions SARA à partir d'une technique de séparation HPLC modifiée - Ces dernières années, une réduction mondiale des réserves de pétrole conventionnel pouvant être exploitées a amené à une augmentation des activités d'exploration et de production des pétroles bruts les plus lourds. Au Canada, il a été demandé aux unités de valorisation d'étudier les pétroles lourds et les bitumes provenant des sables bitumineux, plus accessibles mais plus difficiles à exploiter. Afin d'améliorer les conditions de fonctionnement des installations et d'évaluer leur impact sur l'environnement, une connaissance approfondie de la structure moléculaire et du comportement du pétrole source est nécessaire. Les problèmes liés aux hydrotraitements des fractions riches en azote sont particulièrement préoccupants. L'approche utilisée ici implique la séparation d'une série de divers pétroles bruts canadiens (bitumes provenant des sables bitumineux et pétroles lourds et conventionnels) ayant des teneurs en asphaltènes et maltènes variables, suivie d'un fractionnement supplémentaire des maltènes au moyen de la Chromatographie en Phase Liquide à Haute Performance (HPLC). Cette approche diffère de la séparation conventionnelle SARA (saturés, aromatiques, résines et asphaltènes) car les multiples fractions sont facilement séparées sur la base des différences de polarité et fournissent de ce fait des informations plus détaillées sur la répartition des classes de composants. Les fractions séparées peuvent être caractérisées au moyen de différentes méthodes analytiques, y compris : chromatographie par perméation de gel (GPC) pour déterminer le poids moléculaire moyen, le calcul de paramètres moléculaires en utilisant les analyses CHNS en association avec la spectroscopie ${ }^{1} \mathrm{H}$ et ${ }^{13} \mathrm{C}$ NMR et l'analyse XPS de groupes chimiques au moyen de la déconvolution de pic. Les bitumes contiennent moins de saturés mais plus de résines et d'asphaltènes que tous les autres pétroles lourds testés. A l'inverse, le pétrole conventionnel est associé à un contenu en saturés plus élevé et à la quantité de résines et d'asphaltènes la moins importante. Les rendements en fractions aromatiques provenant de différentes sources sont tous situés dans une gamme relativement étroite. Il est remarquable que les fractions SARA de chaque pétrole aient des propriétés moyennes en masse relativement voisines. Toutes les fractions résines contenaient plus de $40 \%$ de l'azote total, c'est-à-dire plus que les quantités contenues dans les fractions correspondantes d'asphaltène. On a observé, pour les sous-fractions de résines, des différences relativement moins importantes entre les poids moléculaires, les ratios $\mathrm{H} / \mathrm{C}$ atomiques et l'aromaticité $\left(\mathrm{C}_{\mathrm{ar}}\right)$. La différence substantielle dans le comportement de l'élution HPLC pour ces sousfractions semble pouvoir être attribuée à la distribution asymétrique des composants azotés polaires pour
\end{abstract}


les fractions recueillies à des durées d'élution plus longues. Cette observation peut permettre une élimination sélective des composants azotés intraitables, et peut permettre des économies au moyen de l'utilisation d'un catalyseur plus performant dans un processus modifié.

\begin{abstract}
Canadian Crudes: A Comparative Study of SARA Fractions from a Modified HPLC Separation Technique - In recent years, a worldwide reduction in economically recoverable conventional petroleum reserves has led to an increase in exploration and production activity in heavier crude oils. In Canada, up-graders have been required to deal with more accessible, but difficult to process, heavy oils and bitumen from oil sands. In order to optimize plant operating conditions and assess their impact on the environment, a thorough knowledge of the molecular structure and behaviour of the source petroleum is needed. The problems associated with hydro-processing of fractions rich in nitrogen is of particular concern.The approach applied here involves separation of a series of diversified Canadian crude oils (oil sands bitumens plus heavy and conventional oils) into asphaltenes and maltenes, followed by further fractionation of the maltene components by High Performance Liquid Chromatography (HPLC). This approach differs from conventional SARA (saturates, aromatics, resins, asphaltenes) separation in that multiple fractions are easily separated on the basis of polarity differences thereby providing more detailed information on component class distribution. The separated fractions are subjected to characterization by various analytical methods, including: gel permeation chromatography (GPC) for number average molecular weight determination, molecular parameter calculation using CHNS analyses in combination with ${ }^{1} \mathrm{H}$ and ${ }^{13} \mathrm{C} N \mathrm{NR}$ spectroscopy and group analysis by peak deconvolution of X-ray photo-electron spectra (XPS). The bitumens comprise less saturates but more resins and asphaltenes than any of the other heavy oils tested. Conversely, the conventional crude is associated with the highest saturates content and the least amount of resins and asphaltenes. Yields of aromatic fractions from different sources all fall within a relatively narrow range. It is noteworthy that the SARA fractions from each oil produced relatively similar bulk property values. All of the resin fractions contained more than $40 \%$ of the total nitrogen, i.e., greater than the amounts contributed by the corresponding asphaltene fractions. For the resin sub-fractions relatively minor differences between molecular weights, atomic $\mathrm{H} / \mathrm{C}$ ratios and aromaticity $\left(C_{a r}\right)$ were observed. The substantial difference in the HPLC elution behaviour for these subfractions appears to be attributable to the asymmetric distribution of polar nitrogen compounds for material collected at longer elution times. This observation may allow selective removal of intractable nitrogen compounds, possibly leading to cost savings through improved catalyst utilization in a modified upgrading process.
\end{abstract}

\section{NOMENCLATURE}

"A" through "G" Heavy oil samples

Bit1

Bit2

BS

Conv

GPC

HPLC

$M W_{n}$

NMR

$R 1 ; R 2 ; R 3$

SARA

XPS
Ex-situ coker feed bitumen

In-situ bitumen

Bitumen associated solids

Pipeline blend of conventional crudes

Gel Permeation Chromatography

High Performance Liquid Chromatography

Number average molecular weight

Nuclear magnetic resonance

Resin sub-fractions with progressively longer chromatographic elution times

Saturates, aromatics, resins, asphaltenes

$\mathrm{X}$-ray Photoelectron Spectroscopy

\section{INTRODUCTION}

As the worldwide supply of light crude oil decreases the need to utilize heavy oils, including bitumen, is becoming increasingly necessary. Conversion of the gas oils from these unconventional feedstocks to high quality transportation fuels must be accomplished by a combination of hydrocracking and hydrotreating (Yui, 1989; Bej et al., 2001). In this regard, it is well known that gas oils from bitumen and heavy oil are difficult to convert because conventional catalysts are deactivated more rapidly than expected as a result of high levels of intractable nitrogen compounds in these feedstocks. New, alternative catalysts have shown only limited improvements in longevity. As a consequence, treatment of gas oils from these unconventional sources requires process modification in order to meet the specifications of downstream refineries that complete their conversion. A potential key for the 
attainment of this goal is an understanding of the differences between the molecular chemistry of crudes from both conventional and unconventional sources.

In earlier work with coker feed bitumen and coker gas oils (Woods et al., 2004a, b) we compared the molecular chemistries of samples separated by high performance liquid chromatography (HPLC). This approach is an improvement on the traditional SARA separation in that additional subfractions of each resin component can be separated based on interactions with the column material caused by the polarity differences between component classes. This method allows more detailed information on compound class distribution to be determined and is expected to be useful in designing advanced upgrading processes. This is particularly important for oils containing higher amounts of nitrogen species as certain of these components are intractable to conventional upgrading and refining processes (Thompson and Holmes, 1985; Benyamna et al., 1991; Williams and Chishti, 2001).

We now extend this approach to compare bitumens extracted by ex-situ (surface mined from Athabasca oil sands) and in-situ (steam stimulation) methods. For comparison purposes, we include several heavy oils from Saskatchewan and an Alberta conventional crude oil pipeline blend.

\section{EXPERIMENTAL}

\subsection{Samples}

Syncrude Research Ltd. provided ex-situ coker feed bitumen from Athabasca mined oil sands, (Bit1); Nexen supplied Athabasca in-situ bitumen (Bit2). The University of Regina made available samples of seven heavy oils from various reservoirs in Saskatchewan (A through G). The Alberta pipeline blend of conventional crudes (Conv) was obtained from Natural Resources Canada.

\subsection{Separation}

All oil samples were treated with a large excess of n-pentane to remove the asphaltene fraction (Mitchell and Speight, 1973). Any solids (BS), closely associated with the separated asphaltene component, were quantitatively removed by an ultra-centrifugation procedure described elsewhere (Kotlyar et al., 1998).

A Waters Ltd. HPLC System provided the means for group separation of the maltene fraction according to the method described previously (Woods et al., 2004a, b). The equipment comprised a model 600E pump, a model 717 auto-sampler and a Millennium 32 equipped workstation. The system included a model 996 photo diode array ultraviolet (UV) and model 410 refractive index (RI) detectors.

In order to collect sufficient amounts of material for further characterization, a preparative $20 \mathrm{~mm} \times 250 \mathrm{~mm} \mathrm{NH} 2$
Waters Ltd. column was used with hexane as the mobile phase at a flow rate of $5-\mathrm{mL} / \mathrm{min}$. The separation feedstock was $100-\mathrm{mL}$ of 5 -wt./vol.\% maltene solution in hexane. After 25-min. methyltertbutylether was introduced as a second solvent. Injections of $1.5-\mathrm{mL}$ allowed collection of $75-\mathrm{mg}$ of samples during each separation. The photodiode array detector was set to collect UV signal data for wavelengths from 240 to $400 \mathrm{~nm}$, a range particularly sensitive for samples with high contents of aromatic molecules or heteroatoms.

\subsection{Analyses}

Carbon, hydrogen, nitrogen, sulphur contents were determined using a LECO CHNS-932 analyser. Oxygen contents were estimated by difference with spot checks made using a LECO oxygen analyzer attachment.

Gel Permeation Chromatography (GPC) was used to measure number average molecular weights $\left(M W_{n}\right)$ for each sample with reference to polystyrene standards. Tetrahydrofuran at $40^{\circ} \mathrm{C}$ was the solvent with injection volumes of $0.1-\mathrm{mL}$ at a concentration of $0.5-\mathrm{w} / \mathrm{w}$ percent.

For X-ray photoelectron spectroscopy (XPS) the samples were analyzed, using a Kratos Axis Ultra unit equipped with a monochromated $\mathrm{Al} \mathrm{X-ray} \mathrm{source.} \mathrm{Three} \mathrm{analyses} \mathrm{were} \mathrm{per-}$ formed on each sample to ensure reproducibility. Analyses were carried out using an accelerating voltage of $14 \mathrm{kV}$, a current of $10 \mathrm{~mA}$ and an X-ray spot size of $400 \times 700 \mu \mathrm{m}$. Compensation for charge build-up was achieved with the Axis charge balancing system. The pressure in the analysis chamber during analysis was $2.0 \times 10^{-9}$ torr. High resolution spectra were collected at a pass energy of $40 \mathrm{eV}$ and peak fitted using CasaXPS (ver. 2.2.107) data processing software. Shirley background correction procedures were used as provided by CasaXPS. For high resolution spectra a GaussianLorentzian function curve fitting procedure was used. High resolution analyses were calibrated to the adventitious $\mathrm{C} 1 \mathrm{~s}$ signal, at $285 \mathrm{eV}$. Quantification was performed using sensitivity factors provided by CasaXPS's Scofield element library.

Proton Nuclear Magnetic Resonance ( ${ }^{1} \mathrm{H}$ NMR) measurements were made with a Varian Unity Inova 400-MHz spectrometer, using a $5 \mathrm{~mm}$, 4-nucleus probe. Measurements for ${ }^{13} \mathrm{C}$ NMR were made with the same spectrometer equipped with a $5 \mathrm{~mm}$ Broadband Probe.

\section{RESULTS AND DISCUSSION}

\subsection{Parent Oils}

The bulk properties of the parent oils are summarized in Table 1; included are the calculated $\mathrm{H} / \mathrm{C}$ ratios. We note a tendency for $M W_{n}$ to decrease slightly as the oils become 
lighter (lower asphaltene content) whereas $\mathrm{H} / \mathrm{C}$ ratios increased significantly. Overall, nitrogen contents were quite similar for each oil. On the other hand, sulphur contents exhibited appreciable variation but on average the results trended to lower values for the lighter oils.

TABLE 1

Properties of parent crude oils

\begin{tabular}{l|c|c|c|cc}
\hline \multirow{2}{*}{ Crude type } & \multirow{2}{*}{ ID } & \multirow{2}{*}{$M W_{n}$} & \multirow{2}{*}{$\mathrm{H} / \mathrm{C}$} & \multicolumn{2}{|c}{$\mathrm{Wt} \%$} \\
\cline { 5 - 6 } & & & & $\mathrm{N}$ & $\mathrm{S}$ \\
\hline Bitumen & Bit1 & 498 & 1.44 & 0.52 & 4.68 \\
\hline & $\mathrm{Bit} 2$ & 588 & 1.46 & 0.63 & 5.70 \\
\hline Heavy oil & $\mathrm{A}$ & 459 & 1.52 & 0.48 & 3.07 \\
\hline & $\mathrm{B}$ & 462 & 1.53 & 0.47 & 4.99 \\
\hline & $\mathrm{C}$ & 453 & 1.57 & 0.51 & 5.10 \\
\hline & $\mathrm{D}$ & 468 & 1.61 & 0.45 & 5.28 \\
\hline & $\mathrm{E}$ & 440 & 1.52 & 0.56 & 3.64 \\
\hline & $\mathrm{F}$ & 465 & 1.66 & 0.49 & 3.21 \\
\hline & $\mathrm{G}$ & 441 & 1.58 & 0.54 & 3.10 \\
\hline
\end{tabular}

\subsection{SARA Separations}

After removal of asphaltenes, the maltenes were separated into saturates, aromatics and resins by a standard HPLC fractionation technique. The yields (wt.\% of the original crude) for these components and the corresponding asphaltene fractions are shown in Figure 1. Comparing bitumens and heavy oils, we observed that, as expected, the former are associated with less saturates (16-17\% vs. 23-30\%), more resins (37\% vs. $29-33 \%)$ and more asphaltenes (18-21\% vs. 10-16\%) than the latter. Compared to the heavier oils, the conventional crude sample contained a much higher amount of saturates (53\%) but lower concentrations of both resins (19\%) and asphaltenes (3\%). On the other hand, the yields of aromatics from all crude sources fell within the relatively narrow range of $25-32 \%$.

Of interest is the observation that asphaltenes from in-situ bitumen (Bit2), heavy oils (A through G) and conventional (Conv) crude samples are practically free of associated solids (BS). However, the asphaltene fraction from ex-situ bitumen (Bit1) contains up to $5-\mathrm{w} / \mathrm{w} \%$ of BS, i.e., $1 \%$ of the original bitumen. Earlier work demonstrated that all mineral solids were precipitated with the asphaltene material during separation of this component. Solids are separated from the asphaltene fraction by re-dissolving in toluene and subjecting the solutions to ultra-centrifugation under predetermined conditions (Kotlyar et al., 1998).

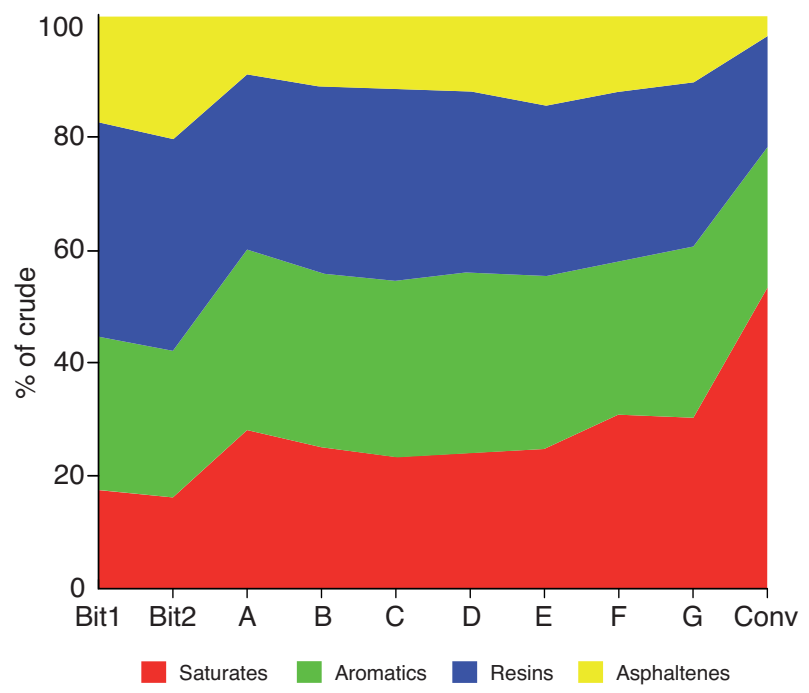

Figure 1

Yields of SARA fractions.

In recognition of the potentially detrimental role played by BS in oil processing, the properties of these solids have been the subject of detailed examination (Kotlyar et al., 1999; Bensebaa et al., 2000). These mineral rich solids are predominantly nano-sized, aluminosilicate clay particles with a patchy surface coverage of polar aromatic toluene insoluble organic matter. This latter feature produces solids that exhibit biwettable characteristics with respect to oil and water. The ultra-fine BS particles from mined, extracted oil sands bitumen have similar properties to solids that concentrate in waste units, i.e., those layers of relatively barren ore separating bitumen rich, oil sands strata. Owing to imperfect excavation practices it is possible that this mine waste material is the primary source of solids associated with bitumen from ex-situ ore. During conditioning in water based extraction processes, some BS particles become dispersed to form a stable, colloidal system in the bitumen phase. Our results, showing that bitumen and heavy oils produced by in-situ methods are practically solids free, support this point of view.

\subsection{Molecular Weight and Elemental Analysis}

Measurement of molecular weights of petroleum fractions, particularly the asphaltene component is a contentious issue. A recent comparison of methods and their potential problems is available elsewhere (Strausz and Lown, 2003; Mullins, 2007). The GPC method used here is open to specific criticisms. It is based on size exclusion from pores of different diameters and consequently has problems when molecular 
aggregation occurs; this could be an issue for asphaltene molecules which are believed to undergo a form of micellization, even at very low concentrations (Sheu and Storm, 1995). However, there is no indication in the literature that nonasphaltene components (maltenes) form aggregates. Also, the selection of suitable standards may be a problem because of different molecular shapes or steric effects. However, we previously measured molecular weights of coker gas oil distillate fractions by vapour pressure osmometry (VPO) and found that they agreed reasonably well with the number average molecular weights determined by GPC on the same samples (Woods et al., 2004b); as VPO is based on a colligative property this is a plausible result and also indicates that at least for the gas oil samples the polystyrene standards used were reasonably appropriate.

Molecular weights for the SARA fractions from various sources are summarised in Figure 2; the aromatics had the lowest values increasing through saturates, resins and then asphaltenes. Owing to the possibility of aggregation the GPC $M W_{n}$ values for the asphaltene fractions are suspect. However, it is interesting to note that our results indicate an asphaltene aggregation number of only three to four compared to the GPC $M W_{n}$ values for the corresponding resin fractions. Others (Zhao and Gray, 2001), have observed that the application of rapid thermal shock to asphaltenes produced a decrease in molecular weight by a factor of about three. This occurred without causing any major changes in molecular structure. It may be inferred from this behaviour that the asphaltene molecule comprises several basic units that break apart at the weakest points when subjected to thermal shock, resulting in the formation of three separate molecules having a similar structure to the original basic unit. The most likely break points in such a scenario are sulphide linkages in aliphatic chains connecting the basic units.

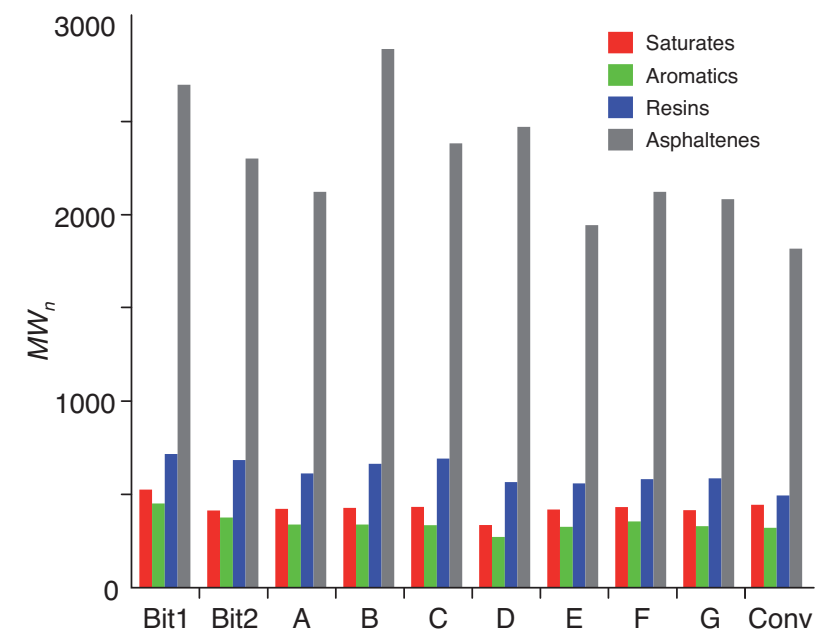

Figure 2

Molecular weights $\left(M W_{n}\right)$ for SARA fractions.

Tables 2 and 3 present a comparison of the hetero-atom (nitrogen and sulphur) contents for each SARA fraction separated from the various oils. As shown in Table 2 the nitrogen contents of the saturate fractions are relatively low in each case but, except for heavy oil B, are slightly higher in the aromatic components. In all cases, nitrogen contents increase rapidly in the resin and asphaltene fractions. Results for each oil show that the resin fractions contain more than $40 \%$ of the total nitrogen, i.e., greater than the amounts contributed by the corresponding asphaltene components.

TABLE 2

Nitrogen analysis of SARA from crude oils

\begin{tabular}{|c|c|c|c|c|c|c|c|c|c|}
\hline \multirow{2}{*}{ Crude type } & \multirow{2}{*}{ ID } & \multicolumn{4}{|c|}{$\mathrm{N}$ (\% of fraction) } & \multicolumn{4}{|c|}{$\mathrm{N}$ (\% of total $\mathrm{N}$ in crude) } \\
\hline & & Saturates & Aromatics & Resins & Asphaltenes & Saturates & Aromatics & Resins & Asphaltenes \\
\hline \multirow[t]{2}{*}{ Bitumen } & Bit 1 & 0.15 & 0.17 & 0.80 & 1.21 & 4.3 & 7.6 & 50.2 & 37.8 \\
\hline & Bit 2 & 0.29 & 0.33 & 0.75 & 1.21 & 6.9 & 12.4 & 41.5 & 38.9 \\
\hline \multirow[t]{7}{*}{ Heavy oil } & A & 0.24 & 0.33 & 0.84 & 1.30 & 11.8 & 18.5 & 45.8 & 23.9 \\
\hline & B & 0.18 & 0.12 & 0.57 & 1.16 & 10.8 & 8.9 & 45.3 & 35.4 \\
\hline & $\mathrm{C}$ & 0.23 & 0.24 & 0.67 & 1.19 & 10.5 & 14.6 & 44.2 & 30.7 \\
\hline & $\mathrm{D}$ & 0.12 & 0.16 & 0.65 & 1.16 & 6.5 & 11.5 & 47.0 & 34.9 \\
\hline & $\mathrm{E}$ & 0.11 & 0.24 & 0.70 & 1.11 & 5.5 & 15.0 & 43.4 & 35.9 \\
\hline & $\mathrm{F}$ & 0.19 & 0.22 & 0.73 & 1.16 & 11.8 & 11.8 & 44.9 & 31.5 \\
\hline & G & 0.22 & 0.26 & 0.80 & 1.19 & 12.8 & 15.2 & 44.8 & 27.2 \\
\hline Conventional & Conv & 0.20 & 0.23 & 0.73 & 1.14 & 30.9 & 16.5 & 41.3 & 11.4 \\
\hline
\end{tabular}


TABLE 3

Sulfur analysis of SARA from crude oils

\begin{tabular}{|c|c|c|c|c|c|c|c|c|c|}
\hline \multirow{2}{*}{ Crude type } & \multirow{2}{*}{ ID } & \multicolumn{4}{|c|}{$\mathrm{S}$ (\% of fraction) } & \multicolumn{4}{|c|}{$\mathrm{S}$ (\% of total $\mathrm{S}$ in crude) } \\
\hline & & Saturates & Aromatics & Resins & Asphaltenes & Saturates & Aromatics & Resins & Asphaltenes \\
\hline \multirow[t]{2}{*}{ Bitumen } & Bit 1 & 0.30 & 3.79 & 6.19 & 7.9 & 1.1 & 20.9 & 47.7 & 30.3 \\
\hline & Bit 2 & 0.23 & 4.40 & 6.97 & 8.65 & 0.7 & 20.1 & 46.0 & 33.2 \\
\hline \multirow[t]{7}{*}{ Heavy oil } & A & 0.14 & 3.24 & 5.10 & 5.99 & 1.2 & 31.5 & 48.2 & 19.1 \\
\hline & B & 0.43 & 4.05 & 7.30 & 8.6 & 2.1 & 25.7 & 49.8 & 22.2 \\
\hline & $\mathrm{C}$ & 0.13 & 5.59 & 7.36 & 8.56 & 0.6 & 32.3 & 46.2 & 20.9 \\
\hline & $\mathrm{D}$ & 0.47 & 5.49 & 7.75 & 8.74 & 2.0 & 31.7 & 45.1 & 21.2 \\
\hline & E & 0.14 & 3.86 & 5.34 & 6.10 & 0.9 & 31.1 & 42.6 & 25.4 \\
\hline & $\mathrm{F}$ & 0.12 & 2.69 & 4.64 & 5.93 & 1.2 & 24.2 & 47.7 & 26.9 \\
\hline & G & 0.16 & 3.45 & 5.15 & 6.04 & 1.5 & 31.6 & 45.3 & 21.7 \\
\hline Conventional & Conv & 0.11 & 2.26 & 3.82 & 4.40 & 3.9 & 36.9 & 49.2 & 9.9 \\
\hline
\end{tabular}

While sulphur contents of the saturate fractions are low, the levels of this element increase dramatically for the other SARA groups; see Table 3. Overall, the resins also accumulate more than $40-\mathrm{w} / \mathrm{w} \%$ of the total sulphur in the parent crude. Oxygen measurements are often problematic and we do not report them here. However, estimation by difference indicated increasing oxygen content for the heavier fractions, peaking in one, or other, of the resin fractions. A few actual measurements, while lower than the estimated values, confirmed this trend. The estimated oxygen content for each asphaltene fraction was always less than the value for the corresponding resin component.

\subsection{Nuclear Magnetic Resonance Results}

Both ${ }^{13} \mathrm{C}$ and ${ }^{1} \mathrm{H}$ are well established spectroscopic techniques that measure the proportion of protons and carbons in specific molecular environments (Bartle et al., 1979; Suzuki et al., 1982). Figure 3 shows typical NMR spectra (results for fractions from heavy oil B). Table 4 outlines the assignments
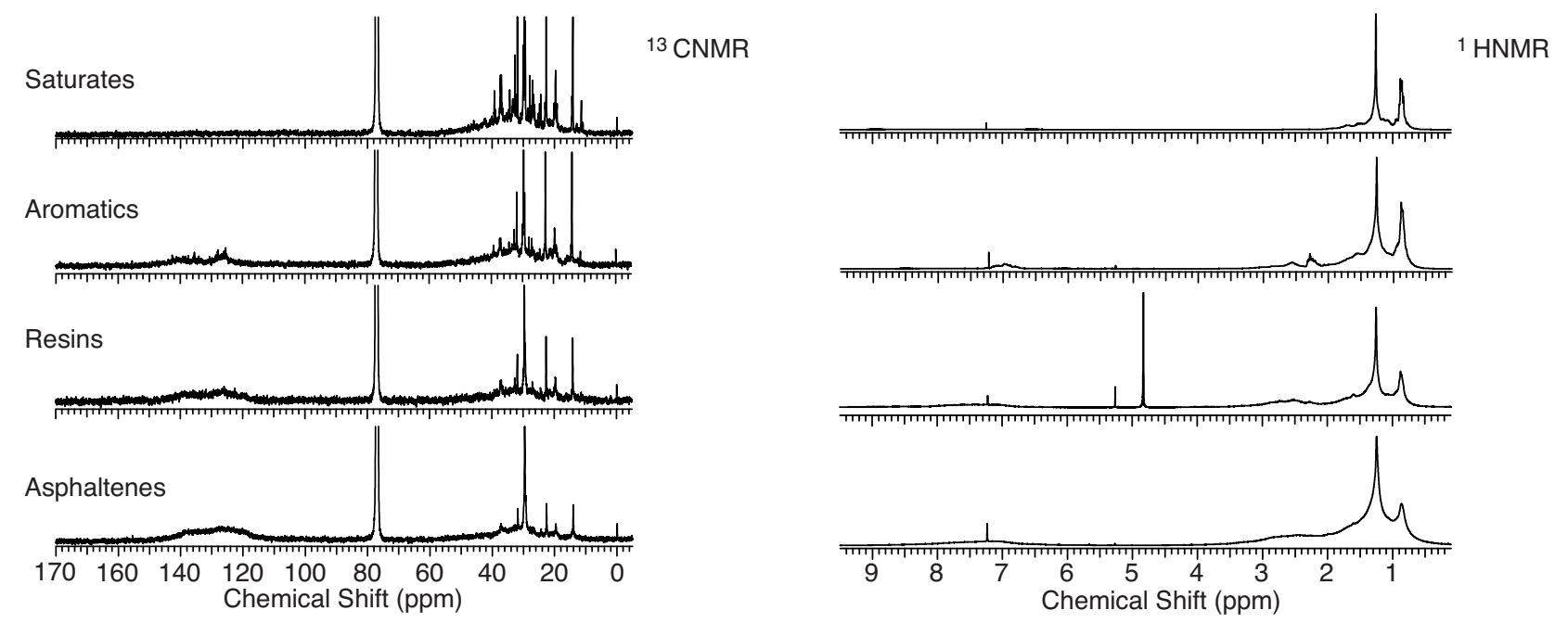

Figure 3

Typical ${ }^{13} \mathrm{C}$ and ${ }^{1} \mathrm{H}$ NMR spectra for SARA fractions (results for the heavy oil B sample). 
TABLE 4

Assignments for ${ }^{1} \mathrm{H}$ and ${ }^{13} \mathrm{C}$ chemical shifts

\begin{tabular}{c|c|c|l}
\hline $\begin{array}{c}\text { Type of } \\
\text { NMR }\end{array}$ & $\begin{array}{c}\text { Chemical Shift Range } \\
(\mathrm{ppm})\end{array}$ & Symbol & Assignment \\
\hline \multirow{4}{*}{${ }^{1} \mathrm{H}$} & $9.3-6.3$ & $\mathrm{H}_{\mathrm{ar}}$ & Aromatic protons. \\
\cline { 2 - 4 } & $4.5-1.9$ & $\mathrm{H}_{\alpha}$ & Protons attached to a saturated $\alpha$-carbon. \\
\cline { 2 - 4 } & $1.9-1.0$ & $\mathrm{H}_{\beta}$ & Protons attached to a saturated $\beta$-carbon or to a $\beta, \gamma$ or $\delta$ (or more) carbon $(\mathrm{CH}, \mathrm{CH})$. \\
\hline \multirow{7}{*}{} & $1.0-0.5$ & $\mathrm{H}_{\gamma}$ & Methyl protons on a $\gamma$ (or more) carbon. \\
\cline { 2 - 4 } & $160-118$ & $\mathrm{C}_{\mathrm{ar}}$ & Aromatic carbons. \\
\cline { 2 - 4 } $\mathrm{C}$ & $70-10$ & $\mathrm{C}_{\mathrm{al}}$ & Aliphatic carbons. \\
\cline { 2 - 4 } & 29.7 & $\mathrm{C}_{29.7}$ & $\begin{array}{l}\text { The resonance at } 29.7 \text { ppm for the internal methylene groups more than three carbons away from } \\
\text { a branching point and more than four from a terminal point. }\end{array}$ \\
\cline { 2 - 4 } & 14.1 & $\mathrm{C}_{14.1}$ & $\begin{array}{l}\text { The resonance at } 14.1 \text { ppm for the terminal methyl carbons in paraffinic straight-chains with four } \\
\text { or more carbons. }\end{array}$ \\
\hline
\end{tabular}

TABLE 5

Relative proportions of different proton and carbon types in SARA fractions from heavy oil B

\begin{tabular}{c|c|c|c|c|c|c|c}
\hline \multirow{2}{*}{ HPLC Fraction } & \multicolumn{7}{|c}{ NMR Parameter } \\
\cline { 2 - 10 } & $\mathrm{H}_{\mathrm{ar}}$ & $\mathrm{H}_{\alpha}$ & $\mathrm{H}_{\beta}$ & $\mathrm{H}_{\gamma}$ & $\mathrm{C}_{\mathrm{ar}}$ & $\mathrm{C}_{29.7}$ & $\mathrm{C}_{14.2}$ \\
\hline Saturates & 2.57 & 1.62 & 63.77 & 32.03 & 4.55 & 6.3 & 2.16 \\
\hline Aromatics & 8.94 & 17.03 & 52.82 & 20.92 & 28.94 & 5.36 & 2.04 \\
\hline Resins & 10.68 & 18.99 & 53.61 & 15.36 & 39.04 & 6.26 & 1.32 \\
\hline Asphaltenes & 10.65 & 20.57 & 53.75 & 15.03 & 46.89 & 6.81 & 0.92 \\
\hline
\end{tabular}

for chemical shifts associated with spectral features. The proportion of protons or carbons in each environment is determined as a fraction of the total number of protons or carbon by comparing specific integrated areas with the total area. As an example, the relative proportions of each proton and carbon type for heavy oil B are shown in Table 5.

Some typical bulk properties of the SARA fractions from the various crude samples are summarized in Figure 4. The decidedly aliphatic nature of saturates is consistent with the high $\mathrm{H} / \mathrm{C}$ ratios and almost zero $\mathrm{C}_{\mathrm{ar}}$ values observed. These results point to increasing aromaticity in the progression from aromatics to resins and are consistent with the observed decreasing trend in $\mathrm{H} / \mathrm{C}$ atomic ratios for these same fractions. Relative to the resins, the asphaltenes are more aromatic with noticeably lower $\mathrm{H} / \mathrm{C}$ ratios. It is noteworthy that the bulk properties of each SARA fraction from every oil sample were quite similar. Based on the results of NMR, elemental analysis and $M W_{n}$ average structural parameters can be calculated, see Table 6. Figure 5 compares calculated parameters ( $L$ and $K$ ) for the same oils. Aliphatic chain length increases rapidly and reaches its highest value in the asphaltene fractions. The results for aromatic ring condensation $(K)$ are less clear cut but indicate a greater degree of condensation in the asphaltenes.

\subsection{Resin Sub-Fractions}

Further fractionation of the resin components from each crude produced three sub-fractions designated $R 1, R 2$ and $R 3$. As shown in Figure 6 these sub-fractions are all associated with a relatively narrow yield range in each case $(R 1=$ $40-50 \%, R 2=28-33 \%$ and $R 3=23-29 \%$ ).

In Figure 7 we compare GPC $M W_{n}$ for these sub-fractions from several typical crude oils. The values for the $R 1$ and $R 2$ fractions are essentially the same while those for the $R 3$ samples are slightly higher but still much lower than those for the corresponding asphaltene components. Here we note that the GPC $M W_{n}$ values for the resin subfractions $R 3$ are of the order of $700 \mathrm{Da}$, close to the value determined for asphaltenes by time resolved fluorescence depolarization (FD) spectroscopy (Groenzin and Mullins, 2000; Badre et al., 2006). In this regard it would be instructive to measure the molecular weights of these resin fractions by the same technique. 


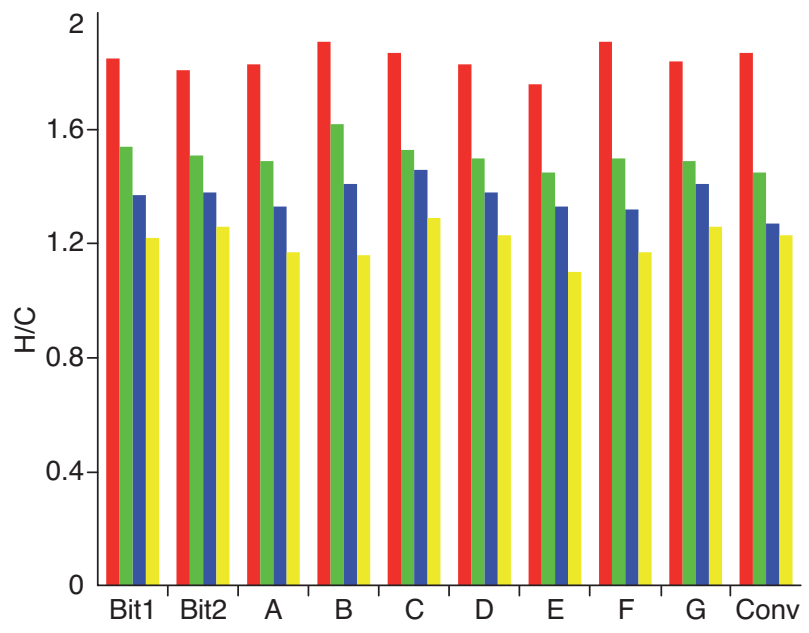

Figure 4

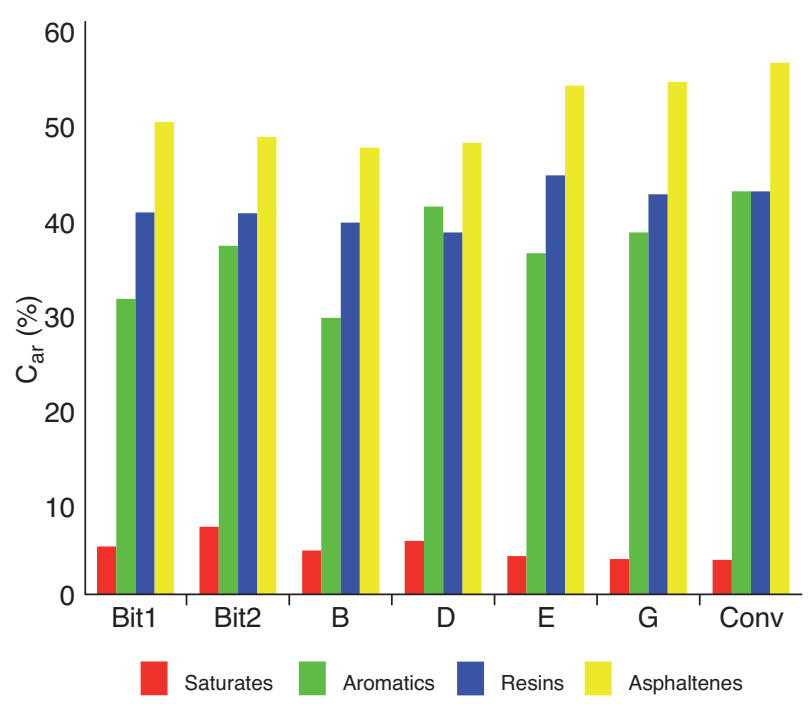

Atomic $\mathrm{H} / \mathrm{C}$ ratios and ${ }^{13} \mathrm{C}$ NMR aromaticities $\left(\mathrm{C}_{\mathrm{ar}}\right)$ for SARA fractions.
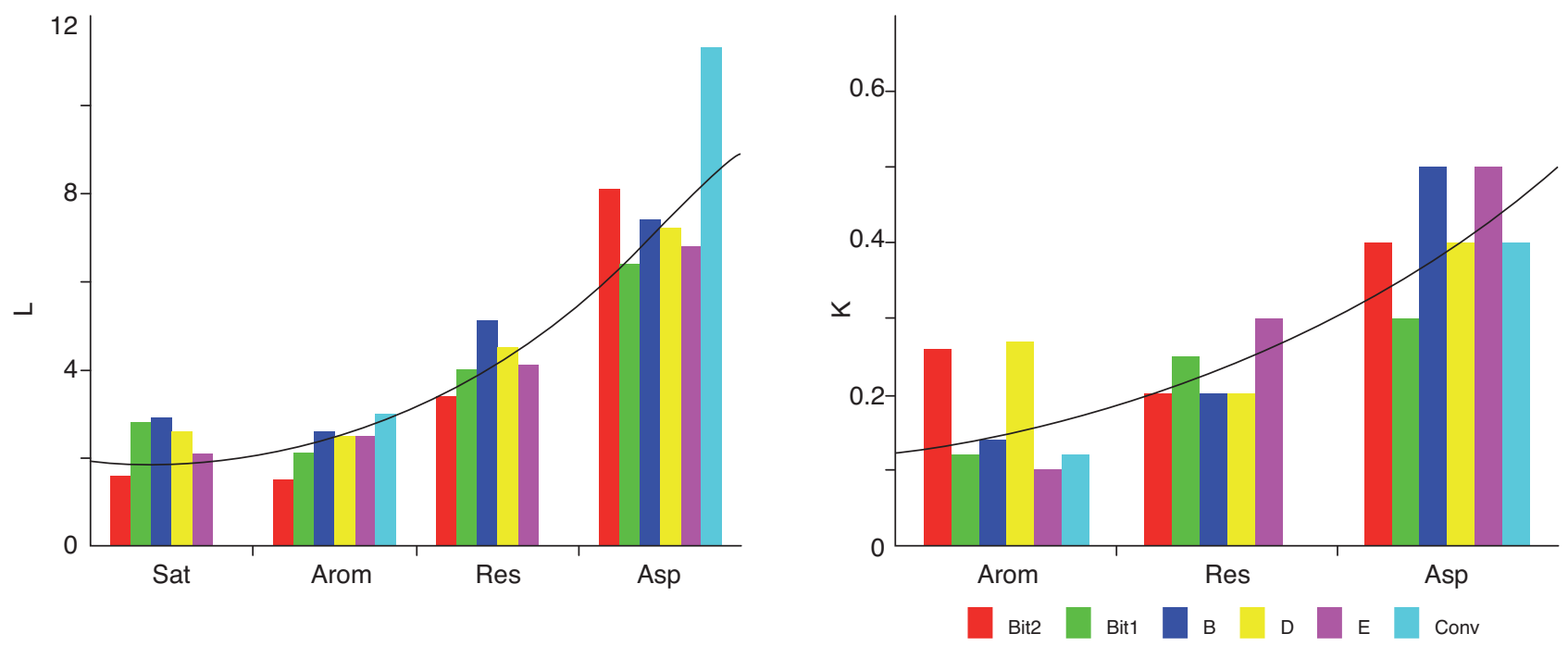

Figure 5

Calculated structural parameters for SARA fractions: aliphatic chain length $(L)$; degree of aromatic ring condensation $(K)$.

It also follows from Figure 7 that there are only minor differences between atomic $\mathrm{H} / \mathrm{C}$ ratios and $\mathrm{C}_{\mathrm{ar}}$ values for resin sub-fractions $R 1$ and $R 3$. In all cases sub-fractions $R 2$ are somewhat more aromatic than $R 1$ and $R 3$. In general, the molecular weights and NMR spectra for the resins and their sub-fractions are very similar both within and between the oil samples tested here. It has been noted elsewhere (Strausz and Lown, 2003; Zhao et al., 2001) that asphaltenes from different sources also exhibit similar structural characteristics.
Tables 7 and 8 summarise the results for heteroatom analyses for the resin sub-fractions. As shown in Table 7 there is a rapid increase in nitrogen content between sub-fractions $R 1$ to $R 3$, approaching the values for the corresponding asphaltene components, compare Tables 2 and 7 . Only minor differences were observed between the nitrogen contents for the corresponding resin sub-fractions from different sources. The $R 1$ sub-fractions accumulate 20 to $27 \%$ of the total nitrogen present in the resins while the remainder is distributed nearly equally between sub-fractions $R 2$ (34-39\%) and $R 3$ 
TABLE 6

Identification and calculation of average structural parameters derived from ${ }^{1} \mathrm{H}$ and ${ }^{13} \mathrm{C}$ NMR (Bartle et al., 1979; Suzuki et al., 1982)

\begin{tabular}{c|l|c}
\hline Symbol & Average parameter & Equation \\
\hline $\mathrm{C}_{\mathrm{ar}}{ }^{\mathrm{n}}$ & Number of aromatic carbon atoms in an average single molecule & $\mathrm{C}_{\mathrm{ar}}{ }^{\mathrm{n}}=\mathrm{C}^{\mathrm{n}} \times \mathrm{C}_{\mathrm{ar}} / 100$ \\
\hline $\mathrm{H}_{\mathrm{ar}}{ }^{\mathrm{n}}$ & Number of aromatic hydrogen atoms in an average single molecule & $\mathrm{H}_{\mathrm{ar}}{ }^{\mathrm{n}}=\mathrm{H}^{\mathrm{n}} \times \mathrm{H}_{\mathrm{ar}} / 100$ \\
\hline $\mathrm{C}_{\mathrm{al}}{ }^{\mathrm{n}}$ & Number of aliphatic carbon atoms in an average single molecule & $\mathrm{C}_{\mathrm{al}}{ }^{\mathrm{n}}=\mathrm{C}^{\mathrm{n}}-\mathrm{C}_{\mathrm{ar}}{ }^{\mathrm{n}}$ \\
\hline $\mathrm{H}_{\mathrm{al}}{ }^{\mathrm{n}}$ & Number of aromatic hydrogen atoms in an average single molecule & $\mathrm{H}_{\mathrm{al}}{ }^{\mathrm{n}}=\mathrm{H}^{\mathrm{n}}-\mathrm{H}_{\mathrm{ar}}{ }^{\mathrm{n}}$ \\
\hline $\mathrm{C}_{\mathrm{c}}{ }^{\mathrm{n}}$ & Number of carbon atoms at condensed points in aromatic ring system in an average single molecule & $\mathrm{C}_{\mathrm{c}}{ }^{\mathrm{n}}=\mathrm{C}_{\mathrm{ar}}{ }^{\mathrm{n}}-\mathrm{H}_{\mathrm{ar}}{ }^{\mathrm{n}}-\mathrm{C}_{\alpha}{ }^{\mathrm{n}}-\mathrm{O}^{\mathrm{n}}$ \\
\hline $\mathrm{C}_{\alpha}{ }^{\mathrm{n}}$ & Number of alkyl substituents on aromatic ring system in an average single molecule & $\mathrm{C}_{\alpha}{ }^{\mathrm{n}}=\mathrm{H}^{\mathrm{n}} \times \mathrm{H}_{\alpha} / r_{\mathrm{al}} \times 100$ \\
\hline$r_{a l}$ & Ratio of aliphatic hydrogen to carbon & $\mathrm{H}_{\mathrm{al}}{ }^{\mathrm{n}} / \mathrm{C}_{\mathrm{al}}{ }^{\mathrm{n}}$ \\
\hline$K$ & Degree of condensation of aromatic ring system & $\mathrm{C}_{\mathrm{c}}{ }^{\mathrm{n}} / \mathrm{C}_{\mathrm{ar}}{ }^{\mathrm{n}}$ \\
\hline $\mathrm{C}_{29.7}{ }^{\mathrm{n}}$ & Number of carbon atoms contained in the at $29.7 \mathrm{ppm}$ in an average single molecule & $\mathrm{C}_{29.7}{ }^{\mathrm{n}}=\mathrm{C}^{\mathrm{n}} \times \mathrm{C}_{29.7} / 100$ \\
\hline $\mathrm{C}_{14.2}{ }^{\mathrm{n}}$ & Number of carbon atoms contained in the at $14.2 \mathrm{ppm}$ in an average single molecule & $\mathrm{C}_{14.2}{ }^{\mathrm{n}}=\mathrm{C}^{\mathrm{n}} \times \mathrm{C}_{14.2} / 100$ \\
\hline $\mathrm{L}$ & Aliphatic chain length & $\mathrm{C}_{29.7} / \mathrm{C}_{14.2}$ \\
\hline
\end{tabular}

$\mathrm{C}_{\mathrm{n}}, \mathrm{H}^{\mathrm{n}}, \mathrm{O}^{\mathrm{n}}$ are the number of carbon, hydrogen, oxygen atoms in an average single molecule, calculated based on the results for molecular weight and elemental analysis.

(34-42\%). It appears that nitrogen species become increasingly concentrated in the last fractions to be eluted during HPLC, indicating that the nitrogen species are more strongly bound to the column material, i.e. that they are more polar than other chemical groups present.

There are relatively insignificant differences between the sulphur contents of each resin sub-fraction from the individual oils, see Table 8 . However, compared to the other heavy oils, the resin fractions from samples B, C and D have significantly higher sulphur contents. Sulphur distribution differs from that of nitrogen in that the highest amounts of sulphur ( $>40 \%$ of that in the total resin fraction) are associated with the $R 1$ sub-fractions. This appears to demonstrate that the sulphur species are less strongly bound to the column mater- ial than the nitrogen compounds predominating in fractions $R 2$ and $R 3$.

Typical X-Ray Photo-Electron Spectra for nitrogen and sulphur are shown in Figure 8. Deconvolution of the spectra allows the identification of specific species as indicated by the dashed curves shown in the figures. Quantification of the data for two samples is summarized in Table 9. These results point to pyrrole as the primary form of nitrogen in both the resin sub-fractions and asphaltenes. Sulphur speciation shows thiophenic sulphur to be the dominant type. The presence of these chemical groups offers an explanation for the observed selectivity for nitrogen versus sulphur in the different HPLC resin fractions. It has been reported (Poulson, 1975; Andersson and Schmid,

TABLE 7

Nitrogen analysis for resin sub-fraction

\begin{tabular}{|c|c|c|c|c|c|c|c|c|c|c|}
\hline \multirow{2}{*}{ Crude type } & \multirow{2}{*}{ ID } & \multicolumn{3}{|c|}{$\mathrm{N}(\%$ of fraction) } & \multicolumn{3}{|c|}{$\mathrm{N}(\%$ of that in resin) } & \multicolumn{3}{|c|}{$\mathrm{N}$ (\% of that in crude) } \\
\hline & & $R 1$ & $R 2$ & $R 3$ & $R 1$ & $R 2$ & $R 3$ & $R 1$ & $R 2$ & $R 3$ \\
\hline \multirow[t]{2}{*}{ Bitumen } & Bit 1 & 0.42 & 0.91 & 1.25 & 21.2 & 37.9 & 40.9 & 10.6 & 19 & 20.5 \\
\hline & Bit 2 & 0.40 & 0.88 & 1.17 & 22.5 & 39.1 & 38.4 & 9.7 & 16.8 & 16.5 \\
\hline \multirow[t]{7}{*}{ Heavy oil } & A & 0.47 & 0.95 & 1.22 & 22.2 & 36.1 & 41.8 & 10.1 & 16.5 & 19.1 \\
\hline & $\mathrm{B}$ & 0.27 & 0.70 & 0.92 & 20.4 & 37.0 & 42.6 & 9.0 & 16.4 & 18.9 \\
\hline & $\mathrm{C}$ & 0.37 & 0.92 & 1.04 & 27.0 & 38.3 & 33.9 & 12.2 & 16.9 & 15.0 \\
\hline & $\mathrm{D}$ & 0.34 & 0.82 & 1.12 & 25.6 & 34.9 & 39.5 & 12.0 & 16.4 & 18.5 \\
\hline & $\mathrm{E}$ & 0.38 & 0.84 & 1.10 & 24.0 & 35.6 & 40.4 & 10.4 & 15.4 & 17.5 \\
\hline & $\mathrm{F}$ & 0.49 & 0.83 & 0.98 & 27.3 & 34.6 & 38.2 & 12.2 & 15.5 & 17.1 \\
\hline & G & 0.50 & 0.86 & 1.13 & 24.2 & 34.2 & 41.8 & 10.8 & 15.2 & 18.7 \\
\hline Conventional & Conv & 0.45 & 0.80 & 1.14 & 27.1 & 34.1 & 38.8 & 11.1 & 14.0 & 16.0 \\
\hline
\end{tabular}




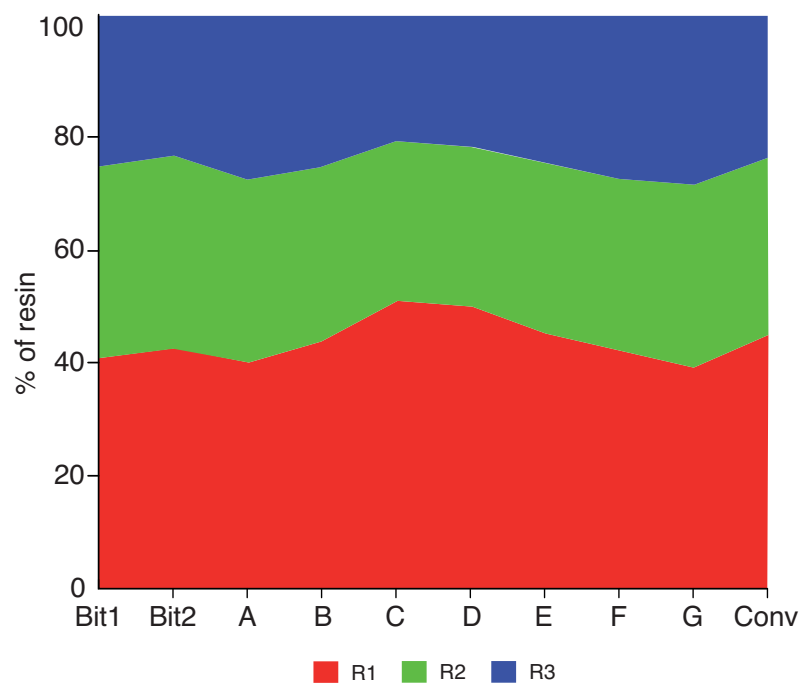

Figure 6

Yields of resin sub-fractions $R 1, R 2$ and $R 3$.

1995) that pyrroles and thiophenes in crude oils occur primarily in the unsaturated form. Unsaturated pyrrole compounds have a significantly greater dipole moment than the corresponding thiophene analogue (Laidig et al., 1996) and consequently will tend to be more difficult to elute during HPLC separation. Unlike the case for nitrogen, the estimated oxygen contents do not seem to correlate with the observed elution behaviour of the resin sub-fractions.

\section{CONCLUSIONS}

Bitumens are associated with less saturates but more resins and asphaltenes than any of the heavy oils tested. Conversely, the conventional crude contains the highest saturates content with the least amount of resin and asphaltenes. The aromatics from different sources are all associated with relatively narrow yield ranges. The asphaltenes from ex-situ bitumen contains more than $5-\mathrm{w} / \mathrm{w} \%$ of BS whereas asphaltenes from all other sources are essentially solids free.

The properties of the resin fractions from each oil tested were quite similar; asphaltenes from different sources show a similar correspondence in properties. In all cases, nitrogen content increases rapidly in the resin and asphaltene fractions. In fact, resins contain more than $40 \%$ of the total nitrogen, an amount greater than that contributed by the corresponding asphaltene fractions. Sulphur contents increase almost monotonically for saturates through asphaltenes.

The number average GPC molecular weights for resins exhibited a value of about one third that of the corresponding asphaltene fraction. Each resin sub-fractions had
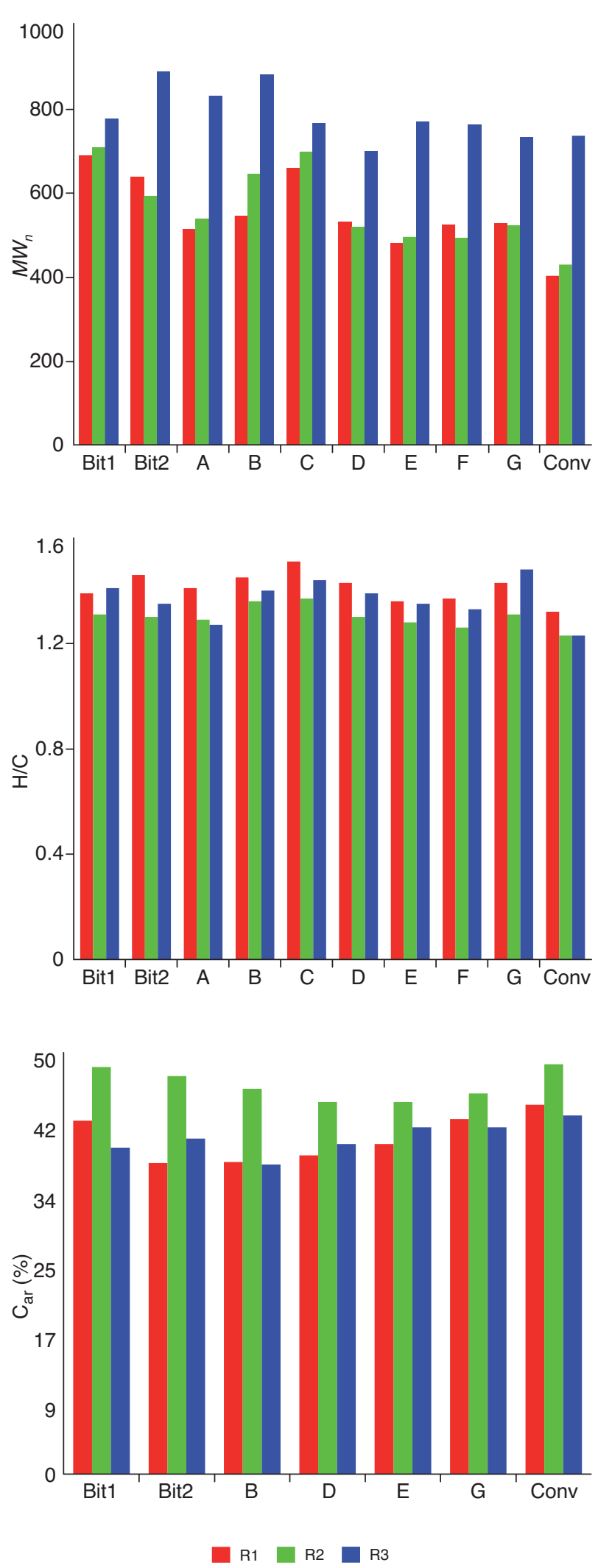

Figure 7

Molecular weights $\left(M W_{n}\right), \mathrm{H} / \mathrm{C}$ ratios and ${ }^{13} \mathrm{C}$ NMR aromaticities $\left(\mathrm{C}_{\mathrm{ar}}\right)$ for resin sub-fractions. 
TABLE 8

Sulphur analysis for resin sub-fractions

\begin{tabular}{|c|c|c|c|c|c|c|c|c|c|c|}
\hline \multirow{2}{*}{ Crude type } & \multirow{2}{*}{ ID } & \multicolumn{3}{|c|}{$\mathrm{S}$ (\% of fraction) } & \multicolumn{3}{|c|}{$\mathrm{S}(\%$ of that in resin) } & \multicolumn{3}{|c|}{$\mathrm{S}$ (\% of that in crude) } \\
\hline & & $R 1$ & $R 2$ & $R 3$ & $R 1$ & $R 2$ & $R 3$ & $R 1$ & $R 2$ & $R 3$ \\
\hline \multirow[t]{2}{*}{ Bitumen } & Bit 1 & 6.50 & 5.85 & 6.18 & 42.4 & 31.5 & 26.1 & 20.2 & 15.0 & 12.5 \\
\hline & Bit 2 & 7.52 & 6.73 & 6.34 & 45.4 & 32.2 & 22.4 & 21.9 & 15.5 & 10.8 \\
\hline \multirow[t]{7}{*}{ Heavy oil } & A & 5.28 & 4.71 & 5.30 & 40.9 & 29.3 & 29.8 & 20.1 & 14.5 & 14.7 \\
\hline & $\mathrm{B}$ & 7.67 & 6.79 & 7.29 & 45.4 & 28.2 & 26.5 & 21.9 & 13.6 & 12.8 \\
\hline & $\mathrm{C}$ & 8.07 & 6.79 & 6.44 & 55.1 & 25.8 & 19.2 & 25.4 & 11.9 & 8.9 \\
\hline & $\mathrm{D}$ & 8.26 & 7.29 & 7.2 & 52.5 & 26.2 & 21.4 & 23.6 & 11.8 & 9.6 \\
\hline & $\mathrm{E}$ & 5.49 & 5.16 & 5.28 & 45.7 & 28.8 & 25.5 & 19.5 & 12.3 & 10.9 \\
\hline & $\mathrm{F}$ & 4.50 & 4.30 & 5.22 & 39.6 & 28.3 & 32.1 & 18.9 & 13.5 & 15.3 \\
\hline & G & 5.08 & 4.68 & 5.73 & 38.2 & 28.8 & 32.9 & 17.3 & 13.0 & 14.9 \\
\hline Conventional & Conv & 3.99 & 3.52 & 3.90 & 45.9 & 28.6 & 25.4 & 22.6 & 14.1 & 12.5 \\
\hline
\end{tabular}
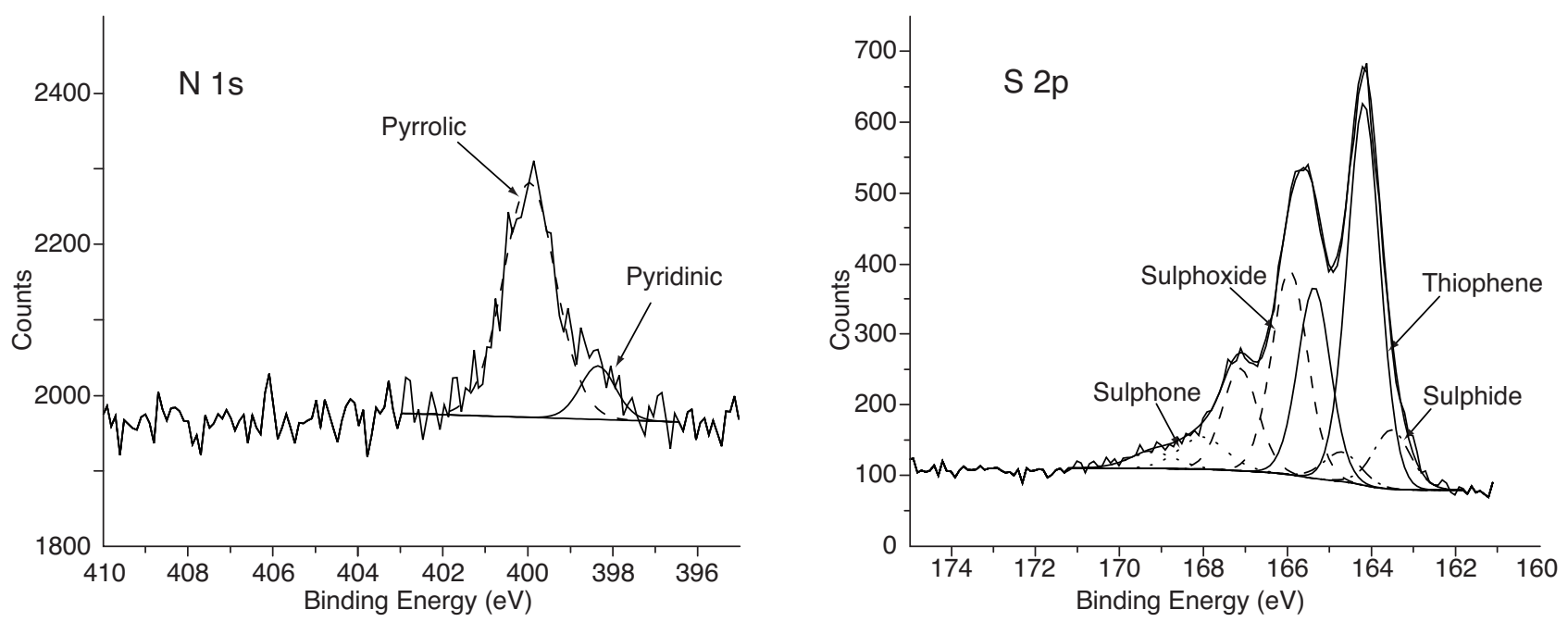

Figure 8

Typical X-Ray Photo-Electron Spectra for nitrogen (N) and sulphur (S). Deconvoluted spectra for specific species are indicated by the dashed lines.

almost identical $\mathrm{H} / \mathrm{C}$ atomic ratios and there were only minor differences between the resin sub-fractions in terms of aromaticity. Compared to $R 2$ and $R 3$ sub-fractions, the $R 1$ fractions are enriched with sulphur. The substantial difference in the HPLC elution behaviour of resins sub-fractions is possibly attributable to increased polarity due to progressively higher nitrogen contents for the samples collected at longer elution times. In each case, pyrrole is the primary nitrogen species whereas thiophenes are the pre- dominant sulphur species. Pyrroles are known to be more polar than their sulphur analogues.

Nitrogen functionalities have a negative influence on refining (Speight, 1999). These components are known to be responsible for poisoning of conventional catalysts. Nitrogen hetero-cycles may also adversely affect the quality of the final product through the formation of insoluble sediments and gums (Mushrush and Speight, 1998). Quantitative data on nitrogen speciation and distribution in 
TABLE 9

XPS analysis for resin sub-fractions and asphaltenes from a bitumen and a heavy oil sample

\begin{tabular}{|c|c|c|c|c|c|c|c|c|}
\hline \multirow{4}{*}{$\begin{array}{c}\text { Element } \\
\text { (atomic \%) }\end{array}$} & \multicolumn{6}{|c|}{ Resin Fraction } & \multirow{2}{*}{\multicolumn{2}{|c|}{ Asphaltenes }} \\
\hline & \multicolumn{2}{|c|}{$R 1$} & \multicolumn{2}{|c|}{$R 2$} & \multicolumn{2}{|c|}{$R 3$} & & \\
\hline & \multicolumn{8}{|c|}{ Parent Crude Type } \\
\hline & Bit 1 & Heavy oil A & Bit 1 & Heavy oil A & Bit 1 & Heavy oil A & Bit 1 & Heavy oil A \\
\hline $\mathrm{C}$ & 92.2 & 92.24 & 94.92 & 93.22 & 93.17 & 92.87 & 92.74 & 92.75 \\
\hline $\mathrm{O}$ & 3.63 & 3.05 & 2.01 & 3.38 & 3.14 & 3.55 & 2.47 & 2.29 \\
\hline \multicolumn{9}{|l|}{$\mathrm{S}$} \\
\hline Total & 2.76 & 3.39 & 2.42 & 2.73 & 2.73 & 2.91 & 3.86 & 3.77 \\
\hline Thiophenic & 1.68 & 1.92 & 1.71 & 1.80 & 1.49 & 1.45 & 2.63 & 2.56 \\
\hline Sulphide & 0.46 & 1.00 & 0.20 & 0.27 & 0.22 & 0.25 & 0.59 & 0.61 \\
\hline Sulphoxide & 0.41 & 0.30 & 0.42 & 0.50 & 0.83 & 0.96 & 0.48 & 0.41 \\
\hline Sulphone & 0.22 & 0.17 & 0.09 & 0.16 & 0.18 & 0.24 & 0.16 & 0.19 \\
\hline \multicolumn{9}{|l|}{$\mathrm{N}$} \\
\hline Total & bdl & bdl & 0.65 & 0.59 & 0.92 & 0.9 & 0.92 & 0.75 \\
\hline Pyrrole & bdl & bdl & 0.59 & 0.51 & 0.80 & 0.61 & 0.73 & 0.61 \\
\hline Pyridine & bdl & bdl & 0.06 & 0.08 & 0.12 & 0.29 & 0.19 & 0.14 \\
\hline
\end{tabular}

bdl $=$ below detection limit.

heavier crude oils is critical for the development of improved processes to either, separate, convert, or transform, these compounds in order to simplify downstream operations.

\section{ACKNOWLEDGEMENT}

We thank Prof. Dong of the University of Regina for supplying heavy oils and Natural Resources Canada for providing the conventional crude. We also acknowledge Nexen for supplying the in situ bitumen sample.

\section{REFERENCES}

Andersson J.T., Schmid B. (1995) Polycyclic Aromatic Sulfur Heterocycles IV. Determination of Polycyclic Aromatic Compounds in a Shale Oil with the Atomic Emission Detector, $J$. Chromatogr. A 693, 325-338.

Badre S., Goncalves C.C., Norinaga K., Gustavson G., Mullins O.C. (2006) Molecular Size and Weight of Asphaltene and Asphaltene Solubility Fractions from Coals, Crude Oils and Bitumen, Fuel 85, $1-11$.

Bartle K.D., Ladner W.R., Martin T.G., Snape C.E., Williams D.F. (1979) Structural Analysis of Supercritical-Gas Extracts of Coals, Fuel 58, 413-422, and references therein.

Bej S., Dalai A., Adjaye J. (2001) Comparison of Hydrodenitrogenation of Basic and Nonbasic Nitrogen Compounds Present in Oil Sands Derived Heavy Gas Oil, Energ. Fuel. 15, 377-383.
Bensebaa F., Kotlyar L.S., Sparks B.D., Chung K.H. (2000) Organic Coated Solids in Athabacsa Bitumen: Characterization and Process Implications, Can. Ch. Engng. J. 78, 610-616.

Benyamna A., Bennouna C., Moreau C., Geneste P. (1991) Upgrading of Distillate Fractions of Timahdit Moroccan Shale Oil over a Sulphided $\mathrm{NiO}-\mathrm{MoO}_{3} / \gamma-\mathrm{Al}_{2} \mathrm{O}_{3}$ Catalyst, Fuel 70, 845-848.

Groenzin H., Mullins O. (2000) Molecular Size and Structure of Asphaltenes from Various Sources, Energ. Fuel. 14, 677-684.

Kotlyar L.S., Sparks B.D., Woods J., Raymond S., Le Page Y., Shelfantook W. (1998) Distribution and Types of Solids Associated with Bitumen, Petrol. Sci. Technol. 16, 1,2, 1-19.

Kotlyar L.S., Sparks B.D., Woods J.R., Chung K.H. (1999) Solids Associated with the Asphaltene Fraction of Oil Sands Bitumen, Energ. Fuel. 13, 346-350.

Laidig K.E., Speers P., Streitwieser A. (1996) Origin of Depressed Dipole Moments in Five Membered, Unsaturated Heterocycles, Can J. Chem. 74, 1215-1220.

Mitchell D.L., Speight J.G. (1973) The Solubility of Asphaltenes in Hydrocarbon Solvents, Fuel 52, 149-152.

Mullins O.C. (2007) Rebuttal to comments, Fuel 86, 309-312.

Mushrush G.M., Speight J.G. (1998) Instability and Incompatibility of Petroleum Products, in Petroleum Chemistry and Refining, Speight J.G. (ed.).

Poulson R.E. (1975) Nitrogen and Sulfur in Raw and Refined Shale Oils, Am. Chem. Soc. Div. Petrol. Chem. 20, 183-197.

Sheu E.Y., Storm D.A. (1995) Colloidal Properties of Asphaltenes in Organic Solvents, in Asphaltenes: Fundamentals and Applications, Sheu E.Y., Mullins O.C. (eds.).

Speight J.G. (1999) The Chemistry and Technology of Petroleum, Marcel Dekker Inc., New York. 
Strausz O.P., Lown E.M. (2003) The Chemistry of Alberta Oil Sands, Bitumen and Heavy Oils, Alberta Energy Research Institute, Calgary.

Suzuki T., Itoh M., Takegami Y., Watanabe Y. (1982) Chemical Structure of Tar-sand Bitumens by ${ }^{13} \mathrm{C}$ and ${ }^{1} \mathrm{H}$ N.M.R. Spectroscopic Methods, Fuel 61, 402-410.

Thompson L.F., Holmes SA. (1985) Effect of Multistage Hydroprocessing on Aromatic and Nitrogen Compositions of Shale Oil, Fuel 64, 9-14.

Williams P.T., Chishti H.M. (2001) Reaction of Nitrogen and Sulphur Compounds during Catalytic Hydrotreatment of Shale Oil, Fuel 80, 957-963.

Woods J., Kung J., Pleizier G., Kotlyar L., Sparks B., Adjaye J., Chung K. (2004a) Characterization of a Coker Gas Oil Fraction from Athabasca Oil Sands Bitumen, Fuel 83, 1907-1914.
Woods J., Kung J., Adjaye J. Kotlyar L., Sparks B., Chung K. (2004b) Characterization of Gas Oil Fractions and Hydrotreated Products, Petrol. Sci. Technol. 22, 3-4, 347-365.

Yui S. (1989) Hydrotreating of Bitumen-Derived Coker Gas Oil: Kinetics of Hydrodesulfurization, Hydrodenitrogenation, and Mild Hydrocracking, and Correlations to Predict Product Yields and Properties, AOSTRA J.Res. 5, 211-224.

Zhao Y., Gray M.R., Chung K.H. (2001) Molar Kinetics and Selectivity in Cracking of Athabasca Asphaltenes, Energ. Fuel. 15, 751-755.

Zhao S., Kotlyar L., Sparks B., Woods J., Gao J., Chung K. (2001) Solids Contents, Properties and Molecular Structures of Asphaltenes from Different Oil Sands, Fuel 80, 1907-1914.

Final manuscript received in September 2007 or distributed for profit or commercial advantage and that copies bear this notice and the full citation on the first page. Copyrights for components of this work owned by others than IFP must be honored. Abstracting with credit is permitted. To copy otherwise, to republish, to post on servers, or to redistribute to lists, requires prior specific permission and/or a fee: Request permission from Documentation, Institut français du pétrole, fax. +33147527078 , orrevueogst@ifp.fr. 